\author{
Anna Irena Szymańska \\ Monika Plaziak \\ Uniwersytet Pedagogiczny \\ im. Komisji Edukacji Narodowej \\ w Krakowie
}

\title{
Klasyczne czynniki w procesie lokalizacji przedsiębiorstwa na wybranych przykładach
}

\author{
Classical factors in enterprise location process on selected examples
}

\begin{abstract}
Streszczenie
W niniejszym artykule poruszono tematykę klasycznych czynników lokalizacji oraz ich znaczenia w wyborze dogodnego miejsca umiejscowienia przedsiębiorstwa w przestrzeni gospodarczej. Należy tu nadmienić, że autorami najważniejszych klasycznych teorii byli m.in. A. Weber, A. Lösch czy A. Predöhl. Jako kluczowe wymieniali oni takie czynniki lokalizacji, jak: koszty transportu, koszty zatrudnienia czy dostępnąść surowców. W artykule podjęto próbę zbadania istoty owych czynników w podejmowaniu decyzji przez współczesnych przedsiębiorców w zakresie lokalizacji ich działalności gospodarczej. Bazę źródłową wykorzystaną w analizach stanowiły wyniki bezpośrednich badań marketingowych, w których uczestniczyło kilkanaście przedsiębiorstw z branży budowlanej.

Zdaniem autorek artykułu, mimo że pierwsze teorie lokalizacji powstały jeszcze w XIX w., klasyczne czynniki lokalizacji nadal są aktualne i nie tracą na znaczeniu. Nieuwzględnienie ich w procesie decyzyjnym w dalszej perspektywie może przyczynić się do niepowodzenia podjętej działalności gospodarczej.
\end{abstract}

\begin{abstract}
This article is focused on the classical factors relating to a location and its importance in the process of choosing a convenient location for an enterprise. The leading classical theories were described in Spatial Management by A.Weber, A. Lösch, A. Predöhl and others. They concentrate on the traditional factors concerning a location, such as transport, labour cost, availability of raw materials or proximity to them.

The paper offers an attempt to analyse the significance of factors influencing a decision-making process used by the contemporary entrepreneurs in connection with the location of their businesses. These analyses draw on results of direct marketing research on a sample of more than a dozen enterprises from the construction sector. The authors believe that, although the first theories on a location date back to 19th century, the classical factors affecting a location continue to be valid and important. If neglected in the decision-making process, they may contribute to a business failure in a longer run.
\end{abstract}

Słowa kluczowe: czynniki lokalizacji; klasyczne czynniki lokalizacji; lokalizacja przedsiębiorstwa; teorie lokalizacji

Key words: classical location factors; enterprise location; location factors; location theories 


\section{Wprowadzenie}

W dobie globalizacji, integracji gospodarczej oraz postępującego oddziaływania nowej gospodarki na otaczającą rzeczywistość obserwuje się załamanie dotychczasowych paradygmatów funkcjonowania przedsiębiorstwa. Konieczna zatem staje się zmiana myślenia oraz strategii zarządzania przedsiębiorstwem. Współczesne realia gospodarcze wymuszają konieczność dostosowywania realizowanych zadań i funkcji oraz metod organizacji zarządzania przedsiębiorstwa do gwałtownie zmieniającego się otoczenia w efekcie procesów transformacji i integracji gospodarczej oraz wyzwań technologicznych i informacyjnych.

Istotnym źródłem przewagi konkurencyjnej staje się również lokalizacja przedsiębiorstwa. Usytuowanie w określonym miejscu w przestrzeni określa dostęp do czynników produkcji czy też rynku zbytu. Determinanta ta określa również możliwości funkcjonowania organizacji w strukturach sieciowych, dostępności do środków publicznych oraz korzystniejszych rozwiązań fiskalnych (szerzej na temat współczesnych czynników lokalizacji: Rachwał, 2011a,b,c; Stryjakiewicz, 2009; Rachwał, Wiedermann, 2008).

Pojęcie lokalizacja (łac. locare) rozumiane jest jako usytuowanie określonej wielkości i rodzaju działalności gospodarczej, obiektu lub grupy obiektów na danym terenie. Pojęcie to rozpatrywane jest zazwyczaj w dwóch aspektach: czynnościowym i rezultatywnym. Ujęcie czynnościowe związane jest z procedurą wyboru rodzaju inwestycji oraz jej miejsca. Natomiast podejście rezultatowe stanowi efekt przeprowadzonej już procedury i dotyczy konkretnej lokalizacji (szerzej na ten temat w: Budner, 2004). Podjęcie decyzji o miejscu usytuowania danego przedsiębiorstwa w przestrzeni przynosi zazwyczaj dalekosiężne, długotrwałe i często nieodwracalne skutki w dalszym jego funkcjonowaniu. Decyzja ta w dalszej perspektywie stanowić będzie tło dla podejmowania kolejnych decyzji w tym zakresie. Decyzje lokalizacyjne podejmowane są w odniesieniu do konkretnego, już istniejącego, układu ekonomiczno-przestrzennego. Stwarza to określone konsekwencje dla działań zmierzających do optymalnego rozmieszczenia nowo projektowanych obiektów (Całczyński, 1981).

W niniejszym artykule poruszono tematykę klasycznych czynników lokalizacji. Podjęto próbę zbadania istoty owych czynników w podejmowaniu decyzji przez współczesnych przedsiębiorców w zakresie lokalizacji ich działalności gospodarczej. Bazę źródłową wykorzystaną w analizach stanowiły wyniki bezpośrednich badań marketingowych, w których uczestniczyło kilkanaście przedsiębiorstw z branży budowlanej. Zdaniem autorów artykułu, mimo że pierwsze teorie lokalizacji powstały jeszcze w XIX w., klasyczne czynniki lokalizacji nadal są aktualne i nie tracą na znaczeniu. Nieuwzględnienie ich w procesie decyzyjnym w dalszej perspektywie może przyczynić się do niepowodzenia podjętej działalności gospodarczej.

\section{Czynniki lokalizacji przedsiębiorstw - zagadnienia teoretyczne}

Zadanie, które postawione zostało przed teorią lokalizacji, to wyjaśnianie i planowanie przestrzennej organizacji różnych rodzajów działalności gospodarczej. Teorię tę można rozpatrywać zarówno w ujęciu mikroekonomicznym, jak i makroekonomicznym. W ujęciu mikroekonomicznym teoria lokalizacji dotyczy jednego przedsiębiorstwa, które uwzględniając koszty i korzyści, poszukuje najlepszego miejsca prowadzenia działalności gospodarczej. W ujęciu makroekonomicznym natomiast teoria lokalizacji jest częścią szeroko rozumianej gospodarki przestrzennej. Podstawę teorii lokalizacji stanowi założenie, że koszty produkcji i dochody przedsiębiorstwa zależą od jego położenia (Budner, 2004).

Pierwsze jej zręby położyli A. Smith i D. Ricardo (twórcy klasycznej teorii ekonomii). Naukowcami, którzy w znacznym stopniu przyczynili się do dalszego rozwoju tej dziedziny nauki 
byli przede wszystkim ekonomiści niemieccy: m.in. J.H. Thünen, W. Launhardt, A. Weber, A. Predöhl, A. Lösch, ekonomiści szwedzcy: B. Ohlin, T. Palander, G. Myrdal oraz ekonomiści amerykańscy: E.M. Hoover i W. Isard.

Badaczem, który jako pierwszy zajął się tematyką lokalizacji przedsiębiorstwa, był W. Launhardt. Uważał on, że idealna lokalizacja to ta, która minimalizuje całkowite koszty transportu przypadające na jednostkę produkcji. Natomiast A. Weber (kontynuator badań W. Launhardta) wprowadził pojęcie czynnika lokalizacyjnego i określił go jako ,jedną z wyraźnie zarysowujących się korzyści, która przejawia się w działalności gospodarczej wówczas, gdy działalność ta jest prowadzona w określonym punkcie lub obszarze. Przez korzyść należy rozumieć oszczędność w kosztach produkcji. Ich osiąganie łączy się z tym, że produkcja określonego wyrobu w danym punkcie lub obszarze odbywa się przy mniejszym nakładzie kosztów niż w każdym innym punkcie lub obszarze" (Budner, 2004). Wyróżnił on trzy czynniki lokalizacyjne: czynnik transportu, czynnik pracy i czynnik aglomeracji. A. Lösch, kontynuując badania nad wyjaśnieniem zachowań lokalizacyjnych, postawił hipotezę o przestrzennej zmienności cen zbytu. Zgodnie z jego koncepcją, lokalizację przedsiębiorstwa można wyznaczyć przez określenie wypadkowej dwóch przeciwstawnych sił, tj. maksymalizacji indywidualnych korzyści oraz maksymalizacji liczby podmiotów gospodarczych (Domański, 2011; Budner, 2004).

A. Predöhl zaś wprowadził teorię substytucji czynników produkcji, przyczyniając się tym samym do stworzenia więzi między teorią ekonomii oraz teorią lokalizacji. Zdaniem A. Predöhla każdy punkt w przestrzeni cechuje określony przydział czynników produkcji. W związku z tym, że ceny owych czynników produkcji w przestrzeni są różne, zmiana lokalizacji z jednego do drugiego punktu wiąże się z substytucją różnych czynników, zależnie od ich względnych cen. Teorię tę rozbudował W. Isard, dodając substytucyjne ujęcie nakładów transportowych.

W efekcie stale zachodzących przemian gospodarczych i społecznych lista czynników lokalizacyjnych nieustannie się powiększa. Zmienia się także ich siła oddziaływania (szerzej na temat ewolucji grupy czynników lokalizacji: Wieloński, 2004). W artykule tym skoncentrowano się jednak tylko na czynnikach sformułowanych przez klasyków teorii lokalizacji oraz ich znaczeniu w decyzjach lokalizacyjnych podejmowanych przez przedsiębiorców w XXI w.

\section{Proces decyzyjny wyboru lokalizacji przedsiębiorstwa}

Wyznaczenie dogodnej lokalizacji działalności jest istotnym zagadnieniem zarówno z punktu widzenia przedsiębiorcy, pracownika, jak i państwa czy też społeczności lokalnej. Coraz częściej przedsiębiorstwa jako miejsce swojej działalności wybierają nie tylko duże miasta, ale również ich strefę podmiejską (Raźniak, 2012), zwiększając tym samym dochody jednostek administracyjnych położonych w strefie podmiejskiej (Raźniak, Winiarczyk-Raźniak, 2013). Właściwy wybór ma swoje odzwierciedlenie w kosztach produkcji ponoszonych przez przedsiębiorstwo, miejscu zamieszkania pracownika, ale także w harmonijnym rozkładzie działalności na określonym obszarze, za co odpowiada państwo lub społeczność lokalna (Perreur, 1992, rozdz. 3).

Działania mające na celu określenie najbardziej optymalnego miejsca lokalizacji przedsiębiorstwa mogą być prowadzone na każdym etapie cyklu rozwoju przedsiębiorstwa. Analiza lokalizacyjna istotna jest w momencie rozpoczynania działalności gospodarczej, kiedy dogodne usytuowanie przedsiębiorstwa korzystnie przyczyni się do efektywnego startu, ale także dalszego jego rozwoju. Podobnie w sytuacji, gdy dalsze prowadzenie określonego typu działalności gospodarczej na danym obszarze przestaje być opłacalne, konieczne staje się wyznaczenie nowej lokalizacji (lub też znacznie rzadziej zmiana rodzaju działalności) (Fierla, Kuciński, 2001). 
Zgodnie z regułą koherencji lokalizacyjnej „właściwa działalność powinna odbywać się na właściwym miejscu" (Budner, 2004). Oznacza to, że każdej działalności przyporządkowane jest określone miejsce, gdzie może być ona realizowana. Nie wszystkie miejsca zapewnią danemu typowi działalności wystarczająco dogodne warunki rozwoju. Z drugiej strony nie wszystkie rodzaje działalności mogą być realizowane w danym miejscu. Każdemu miejscu przyporządkowany jest więc określony rodzaj działalności (porównaj: Zawadzki, 1973; Leśniak, 1985). Regułę koherencji lokalizacyjnej tworzą dwie strony realizacji. Aktywna strona związana jest z poszukiwaniem optymalnych punktów lokalizacji, pasywna zaś - z określeniem najkorzystniejszego przeznaczenia terenów (Leśniak, 1985; Budner, 2004).

Proces decyzyjny prowadzony jest zarówno w oparciu o czynniki egzogeniczne, niezależne od przedsiębiorstwa (m.in. rynek zbytu, rynek zaopatrzenia, nieruchomości, infrastruktura transportowa, rynek pracy, koszty prowadzenia działalności gospodarczej), jak i czynniki endogeniczne - odnoszące się do rodzaju prowadzonej działalności gospodarczej oraz struktury organizacyjnej przedsiębiorstwa. Kluczowi decydenci (inwestorzy, menedżerowie średniego i wyższego szczebla), kierując się zgromadzonymi informacjami jak również własnymi opiniami i preferencjami, dokonują ostatecznego wyboru lokalizacji przedsiębiorstwa (ryc. 1).

Proces poszukiwania dogodnej lokalizacji przedsiębiorstwa rozpoczyna określenie wymogów dotyczących miejsca lokalizacji. Następnie dokonuje się selekcji możliwych lokalizacji na podstawie zdefiniowanego wcześniej zbioru czynników. Ostatecznie wytypowane obszary poddawane są szczegółowej analizie i dokonuje się wyboru najbardziej optymalnego miejsca lokalizacji działalności gospodarczej. Istotne znaczenie w lokalizacji określonego rodzaju

Ryc. 1. Miejsce klasycznych czynników lokalizacji w procesie wyboru lokalizacji przedsiębiorstwa

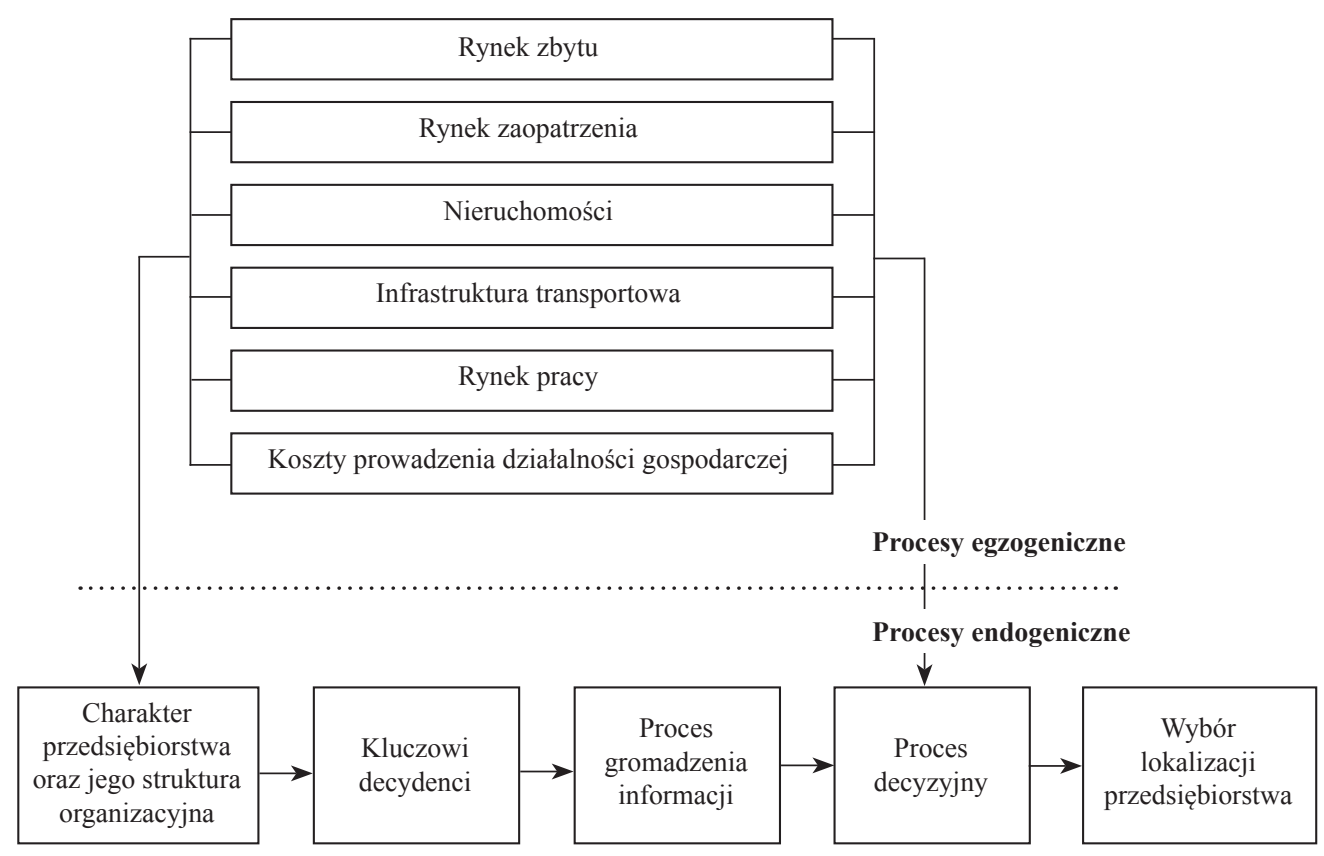

Źródło: opracowanie własne. 
działalności gospodarczej mają walory danego regionu. Jednocześnie należy zwrócić uwagę, że również przedsiębiorstwa lokowane na danym obszarze wpływają na jakość oraz rodzaj owych walorów. Istnieje również pewne zróżnicowanie poszczególnych czynników lokalizacyjnych w ujęciu sektorowym (np. odrębne specjalizacje zawodowe, odrębne grupy poddostawców czy zapotrzebowanie na usługi). Nie należy zapominać o preferencjach decydentów, co do czynników istotnych dla nich przy wyborze miejsca do prowadzenia danej działalności gospodarczej (Pred, 1967).

E.M. Hoover (1962), pisząc o preferencjach lokalizacyjnych producentów, określa je mianem lokalizacji producenta, czyli „najlepszego miejsca do osiągnięcia zarobku”. Jako podstawę preferencji producenta w zakresie wyboru konkretnej lokalizacji wymienia wysokość dochodów (płace, zyski lub procent) możliwych do uzyskania w różnych miejscach. Istotna jest regularność oraz pewność uzyskiwania dochodów jak również przewidywany trend w ich kształtowaniu się. Uogólniając, można powiedzieć, że na kształtowanie preferencji producentów wpływają przede wszystkim takie czynniki, jak stałość, bezpieczeństwo oraz perspektywy na przyszłość. E.M. Hoover zwraca również uwagę na znaczenie preferencji lokalizacyjnych konsumentów (lokalizacja konsumenta) mówiących o tym, gdzie chciałby on mieszkać i wydawać swój dochód. Czynnik ten ma - zdaniem Hoovera - niewielkie znaczenie w decyzjach lokalizacyjnych. Wpływ preferencji konsumentów jest jedynie pośredni i można go rozważać w kontekście preferencji lokalizacyjnych zatrudnianych pracowników oraz inwestorów (Hoover, 1962; porównaj: Kupiec i in., 1999).

Atrakcyjność określonej lokalizacji uzależniona jest od poziomu zgodności cech danego terenu z potrzebami wynikającymi z charakteru działalności, która będzie prowadzona. Analizując stopień przydatności wybranych miejsc do pełnienia określonej funkcji, zależy on od cech, jakie ma wybrany teren, czyli uwarunkowań wewnętrznych, oraz sytuacji panującej w otoczeniu owego terenu (uwarunkowania zewnętrzne). W ramach uwarunkowań wewnętrznych wymienić należy przede wszystkim: warunki naturalne (np. ukształtowanie powierzchni, surowce naturalne, klimat itp.), stan prawny (własność, obciążenie hipoteczne), istniejący sposób zagospodarowania oraz użytkowania terenu. Uwarunkowania zewnętrzne to: również warunki naturalne i ochrona środowiska (ukształtowanie terenu, warunki wodne, gospodarka ściekami i odpadami komunalnymi), warunki społeczno-demograficzne (liczba ludności, struktura wieku, struktura zatrudnienia, saldo migracji, poziom bezrobocia i wykształcenia), struktura przestrzenna otoczenia, relacja przestrzenna w stosunku do rynków zbytu, sytuacja gospodarcza, infrastruktura, uwarunkowania prawne i inne ${ }^{1}$ (Budner, 2004).

\section{Istota klasycznych czynników lokalizacji przedsiębiorstw sektora budowlanego - analiza wyników badań}

W celu empirycznej analizy istoty klasycznych czynników lokalizacji w podejmowaniu decyzji przez współczesnych przedsiębiorców w zakresie lokalizacji ich działalności gospodarczej przeprowadzono marketingowe badania bezpośrednie. W badaniach zastosowano technikę wywiadu pogłębionego oraz bezpośredniego wywiadu kwestionariuszowego, wykorzystując dwa wzory kwestionariuszy:

\footnotetext{
${ }^{1}$ Interesującym przykładem mogą być tu czynniki lokalizacji sprzyjające usytuowaniu przedsiębiorstw agroturystycznych w przestrzeni; zob. Dorocki, Rachwał, Szymańska, Zdon-Korzeniowska, 2012; Dorocki, Szymańska, Zdon-Korzeniowska, 2012; Dorocki, Szymańska, Zdon-Korzeniowska 2013a; Dorocki, Szymańska, Zdon-Korzeniowska, 2013 b.
} 
- kwestionariusz A - z pytaniami dotyczącymi znaczenia klasycznych czynników lokalizacji w usytuowaniu przedsiębiorstwa w przestrzeni gospodarczej,

- kwestionariusz B - dotyczący istoty współczesnych czynników lokalizacji.

W każdym z kwestionariuszy przedstawiono listę czynników lokalizacji uporządkowanych w większe grupy. Kwestionariusz A zawierał 31 czynników uporządkowanych w 6 grup głównych. Kwestionariusz B natomiast uwzględniał 38 czynników w ramach 7 grup głównych. Zadaniem przedsiębiorstw uczestniczących w badaniu było dokonanie oceny ${ }^{2}$ wpływu czynników lokalizacji na decyzję wyboru określonego miejsca w przestrzeni gospodarczej jako docelowego miejsca lokalizacji ich przedsiębiorstwa. W pierwszej kolejności ocenie poddano poszczególne grupy czynników, a następnie poszczególne czynniki cząstkowe w obrębie grupy. Istniała też możliwość wskazania innych czynników lokalizacji, istotnych w odczuciu przedsiębiorców.

Proces gromadzenia danych przebiegał w czterech fazach. Pierwszy etap obejmował badanie pilotażowe (dwa przedsiębiorstwa), służące sprawdzeniu poprawności konstrukcji instrumentu pomiarowego (kwestionariusza) oraz stopnia zrozumienia zawartych w kwestionariuszu sformułowań. Następnie w drugiej fazie (z wykorzystaniem kwestionariusza A) i trzeciej fazie badań (z wykorzystaniem kwestionariusza B) przeprowadzono badania kwestionariuszowe z grupą 53 przedsiębiorców reprezentujących przedsiębiorstwa z branży budowlanej, zlokalizowane na terenie województwa małopolskiego. Ostatecznie analizom poddano 13 poprawnie wypełnionych kwestionariuszy ankiet. Ostatnia, czwarta faza polegała na przeprowadzeniu wywiadu pogłębionego z wybranymi dwoma przedsiębiorstwami i dotyczyła znaczenia personalnego czynnika lokalizacji w podejmowaniu decyzji o miejscu lokalizacji przedsiębiorstw uczestniczących w badaniu.

W niniejszym artykule, którego tematyka koncentruje się przede wszystkim na klasycznych czynnikach lokalizacji oraz ich znaczeniu w podejmowaniu decyzji lokalizacji działalności gospodarczej przez przedsiębiorców, omówione zostały wyniki badań, w których zastosowano kwestionariusz A (porównaj: Szymańska, Płaziak, 2014)33.

W tabeli 1 zaprezentowano listę klasycznych czynników lokalizacji, które zawierał kwestionariusz A. Czynniki te zostały uporządkowane w 6 grup: czynniki rynkowe, czynniki zaopatrzeniowe, czynniki dotyczące nieruchomości, czynniki dotyczące infrastruktury transportowej, czynniki rynku pracy oraz czynniki kosztowe. Doboru czynników lokalizacji dokonano na podstawie literatury przedmiotu, uwzględniając te najczęściej w niej wymieniane.

Jak już wcześniej wspomniano, w pierwszym etapie badania kwestionariuszowego ocenie poddano poszczególne grupy czynników lokalizacji. W opinii przedsiębiorstw sektora budowlanego, uczestniczących w badaniach, najistotniejszym klasycznym czynnikiem bazowym uwzględnianym przy podejmowaniu decyzji o lokalizacji działalności gospodarczej okazał się być rynek zbytu - średnia ocena: 4,31 pkt (ryc. 2). Kolejne dwa czynniki bazowe to koszty prowadzenia działalności gospodarczej (4,08 pkt) oraz rynek pracy $(3,77 \mathrm{pkt})$. Zdecydowanie najsłabiej oceniony został rynek zaopatrzenia $(2,77 \mathrm{pkt})$.

\footnotetext{
2 Przyjęto skalę sześciostopniową, gdzie ocena „5” oznaczała czynnik bardzo ważny, natomiast „0” czynnik nieistotny przy wyborze miejsca lokalizacji przedsiębiorstwa.

${ }^{3}$ Wyniki badań dotyczące znaczenia współczesnych czynników lokalizacji w sytuowaniu przedsiębiorstw w przestrzeni gospodarczej omówiono w artykule: Płaziak, Szymańska, 2014.
} 
Tab. 1. Klasyczne czynniki lokalizacji przedsiębiorstwa

\begin{tabular}{|c|c|}
\hline Lp. & Klasyczne czynniki lokalizacji \\
\hline 1. & $\begin{array}{l}\text { Rynki zbytu (popyt na produkty i usługi) } \\
\text { - Bliskość rynków zbytu } \\
\text { - Bliskość dostawców i kooperantów } \\
\text { - Obecność firm z udziałem kapitału zagranicznego } \\
\text { - Obecność firm liderów danego sektora }\end{array}$ \\
\hline 2. & $\begin{array}{l}\text { Rynki zaopatrzenia (np. baza surowców, źródeł energii, innowacji) } \\
\text { - Dostępność surowców } \\
\text { • Dostępność półproduktów } \\
\text { - Dostępność konwencjonalnych źródeł energii }\end{array}$ \\
\hline 3. & $\begin{array}{l}\text { Nieruchomości (dostęp do komercyjnych gruntów, budynków, lokali oraz wysokość kosztów } \\
\text { ich zakupu lub wynajmu/dzierżawy) } \\
\text { - Dostępność odpowiednich gruntów } \\
\text { - Dostępność odpowiednich budynków biurowych } \\
\text { - Dostępność odpowiednich budynków produkcyjnych i magazynowych } \\
\text { - Dostępność odpowiednich gruntów/budynków, dających możliwość przestrzennego rozszerze- } \\
\text { nia działalności firmy } \\
\text { - Koszty dzierżawy lub zakupu gruntów } \\
\text { - Koszty najmu lub zakupu budynków } \\
\text { - Czas oraz koszty związane z uzyskaniem decyzji pozwolenia na budowę, przyłączenia mediów } \\
\text { - Czas oraz koszty związane z procedurami dotyczącymi przystosowania budynku na potrzeby } \\
\text { prowadzonej działalności gospodarczej }\end{array}$ \\
\hline 4. & $\begin{array}{l}\text { Infrastruktura transportowa (dostęp do krajowych i międzynarodowych autostrad, sieci kolei } \\
\text { oraz portów lotniczych) } \\
\text { - Dogodne położenie w systemie dróg krajowych } \\
\text { - Dogodne położenie w systemie dróg regionalnych i lokalnych } \\
\text { - Stan techniczny nawierzchni oraz przepustowość dróg } \\
\text { - Dogodne położenie w systemie transportu kolejowego } \\
\text { - Dobra dostępność do portów lotniczych } \\
\text { - Dogodny system komunikacji publicznej (pod względem dostępności i częstotliwości } \\
\text { połączeń autobusowych oraz kolejowych) } \\
\text { - Dostępność miejsc parkingowych }\end{array}$ \\
\hline 5. & $\begin{array}{l}\text { Rynek pracy (dostępność i kwalifikacje pracowników oraz koszty pracy) } \\
\text { - Dostępność siły roboczej o odpowiednich kwalifikacje oraz doświadczenie wymagane w danej } \\
\text { działalności gospodarczej } \\
\text { - Dostępność kadry menedżerskiej } \\
\text { - Dostęp do taniej siły roboczej } \\
\text { - Dostęp do tanich specjalistów }\end{array}$ \\
\hline 6. & $\begin{array}{l}\text { Koszty prowadzenia działalności gospodarczej (wysokość lokalnych obciążeń podatkowych, } \\
\text { cen usług komunalnych oraz usług outsourcingowych) } \\
\text { - Wysokość podatków i opłat lokalnych } \\
\text { - Ceny usług transportowych } \\
\text { - Ceny usług komunalnych (energii, wody, gazu) } \\
\text { - Ceny usług outsourcingowych (np. księgowości) } \\
\text { - Ceny usług doradczo-konsultingowych }\end{array}$ \\
\hline
\end{tabular}

Źródło: opracowanie własne na podstawie: Fabińska, Piasecki (Benchmarking regionalny); Tobolska (2011); Wieloński (2004); Dziemianowicz (1997). 
Ryc. 2. Istotność bazowych klasycznych czynników lokalizacji w ocenie przedsiębiorstw uczestniczących w badaniach

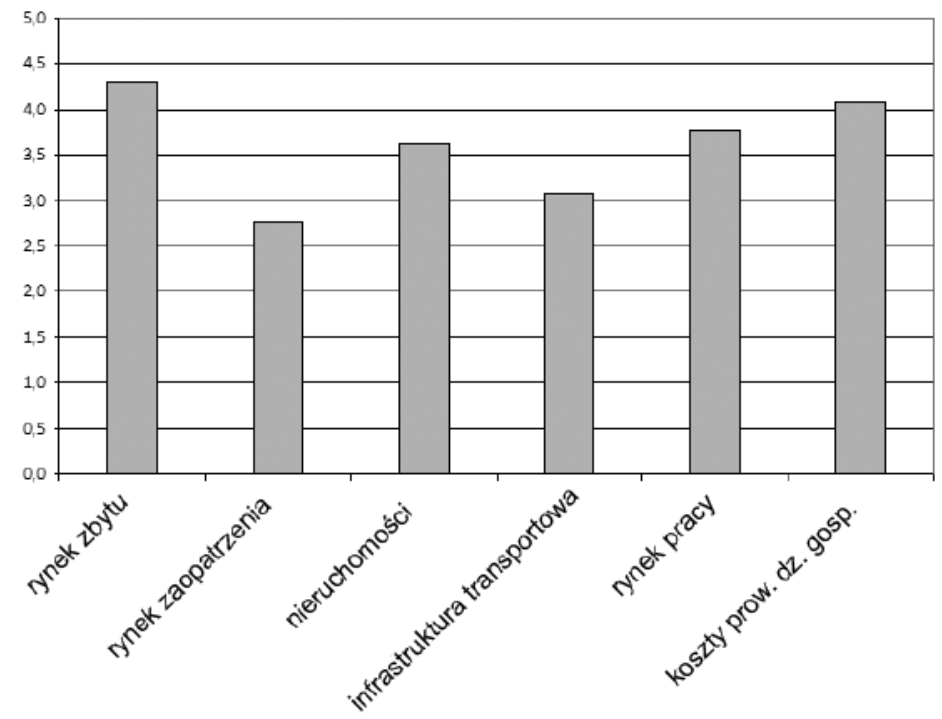

Źródło: opracowanie własne w oparciu o wyniki badań ankietowych.

W drugim etapie badania, z wykorzystaniem kwestionariusza A, ocenie poddano poszczególne czynniki cząstkowe w obrębie grup (tab. 2). Za najistotniejszy wśród grupy czynników rynkowych uznano „,bliskość rynku zbytu” (4,54 pkt). Istotna okazała się również „bliskość dostawców i kooperantów" (3,77 pkt).

W ramach czynników kosztowych jako najważniejsze przy wyborze lokalizacji wymieniono: „wysokość podatków i opłat lokalnych” (4,31 pkt) oraz „,ceny usług komunalnych” (4,00 pkt) i ,ceny usług transportowych” (3,54 pkt). Najniżej ocenione zostały ,ceny usług doradczo-konsultingowych" (3,15 pkt).

W grupie czynników dotyczących dostępności rynku pracy szczególnie ważne okazały się „dostępność siły roboczej o odpowiednich kwalifikacjach oraz doświadczenie wymagane w danej działalności gospodarczej” (3,62 pkt) oraz „dostęp do tanich specjalistów” (3,46 pkt). Natomiast najniżej oceniono „dostępność kadry menedżerskiej” (2,92 pkt).

Kolejna grupa czynników poddanych badaniu to czynniki związane z nieruchomościami. W ramach grupy najwyżej oceniono „koszty dzierżawy lub zakupu gruntów” (4,00 pkt), „czas oraz koszty związane z uzyskaniem decyzji pozwolenia na budowę, przyłączenia mediów" (3,85 pkt) oraz „koszty najmu lub zakupu budynków” (3,69 pkt). Zdecydowanie najniższą ocenę uzyskała „dostępność odpowiednich budynków produkcyjnych i magazynowych” (2,69 pkt). W grupie czynników dotyczących infrastruktury transportowej szczególnie istotna okazała się „dostępność miejsc parkingowych” (4,08 pkt). Jako najistotniejsze czynniki w grupie czynników dotyczących rynku zaopatrzenia wybrano „dostępność surowców” i „dostępność półproduktów (w obu wypadkach 3,31 pkt). 
Tab. 2. Klasyczne czynniki lokalizacji

\begin{tabular}{|c|c|c|}
\hline Lp. & Klasyczne czynniki lokalizacji & $\begin{array}{c}\text { Średnia } \\
\text { ocena }\end{array}$ \\
\hline \multicolumn{3}{|c|}{ Rynki zbytu } \\
\hline 1. & Bliskość rynków zbytu & 4,54 \\
\hline 2. & Bliskość dostawców i kooperantów & 3,77 \\
\hline 3. & Obecność firm z udziałem kapitału zagranicznego & 2,31 \\
\hline 4. & Obecność firm liderów danego sektora & 2,69 \\
\hline \multicolumn{3}{|c|}{ Rynki zaopatrzenia } \\
\hline 5. & Dostępność surowców & 3,31 \\
\hline 6. & Dostępność półproduktów & 3,31 \\
\hline 7. & Dostępność konwencjonalnych źródeł energii & 3,00 \\
\hline \multicolumn{3}{|c|}{ Nieruchomości } \\
\hline 8. & Dostępność odpowiednich gruntów & 3,62 \\
\hline 9. & Dostępność odpowiednich budynków biurowych & 3,31 \\
\hline 10. & Dostępność odpowiednich budynków produkcyjnych i magazynowych & 2,69 \\
\hline 11. & Dostępność odpowiednich gruntów/budynków dla rozszerzenia działalności firmy & 3,38 \\
\hline 12. & Koszty dzierżawy lub zakupu gruntów & 4,00 \\
\hline 13. & Koszty najmu lub zakupu budynków & 3,69 \\
\hline 14. & Czas i koszty związane z uzyskaniem pozwolenia na budowę, przyłączenie mediów & 3,85 \\
\hline 15. & Czas oraz koszty związane z procedurami dotyczącymi przystosowania budynku & 3,54 \\
\hline \multicolumn{3}{|c|}{$\begin{array}{l}\text { Infrastruktura transportowa } \\
\end{array}$} \\
\hline 16. & Dogodne położenie w systemie dróg krajowych & 3,15 \\
\hline 17. & Dogodne położenie w systemie dróg regionalnych i lokalnych & 3,54 \\
\hline 18. & Stan techniczny nawierzchni oraz przepustowość dróg & 3,38 \\
\hline 19. & Dogodne położenie w systemie transportu kolejowego & 1,85 \\
\hline 20. & Dobra dostępność do portów lotniczych & 2,38 \\
\hline 21. & Dogodny system komunikacji publicznej & 3,31 \\
\hline 22. & Dostępność miejsc parkingowych & 4,08 \\
\hline \multicolumn{3}{|c|}{ Rynek pracy } \\
\hline 23. & Dostępność siły roboczej o odpowiednich kwalifikacjach & 3,62 \\
\hline 24. & Dostępność kadry menedżerskiej & 2,92 \\
\hline 25. & Dostęp do taniej siły roboczej & 3,15 \\
\hline 26. & Dostęp do tanich specjalistów & 3,46 \\
\hline \multicolumn{3}{|c|}{ Koszty prowadzenia działalności gospodarczej } \\
\hline 27. & Wysokość podatków i opłat lokalnych & 4,31 \\
\hline 28. & Ceny usług transportowych & 3,54 \\
\hline 29. & Ceny usług komunalnych & 4,00 \\
\hline 30. & Ceny usług outsourcingowych & 3,23 \\
\hline 31. & Ceny usług doradczo-konsultingowych & 3,15 \\
\hline
\end{tabular}

Źródło: opracowanie własne na podstawie wyników badań ankietowych. 
W toku dalszej analizy wyników badań empirycznych dokonano podziału przedsiębiorstw uczestniczących w badaniach na dwie grupy. Uwzględniając jako kryterium podziału charakter prowadzonej działalności gospodarczej, wyszczególniono pięć firm architektonicznych oraz osiem firm budowlanych (tab. 3).

Następnie określono wagę uzyskanych ocen wszystkich czynników należących do danej grupy w stosunku do maksymalnie możliwej do uzyskania oceny w tej grupie (tab. 3). Waga wyliczona została jako udział procentowy sumy uzyskanych ocen w stosunku do maksymalnej, możliwej sumy ocen - „5” pomnożonej przez liczbę czynników w danej grupie.

Tab. 3. Ocena istotności poszczególnych grup klasycznych czynników lokalizacji z uwzględnieniem podziału na firmy architektoniczne oraz firmy budowlane

\begin{tabular}{|c|c|c|c|c|c|c|c|}
\hline \multirow[b]{2}{*}{ Lp. } & \multirow[b]{2}{*}{$\begin{array}{l}\text { Grupy klasycznych } \\
\text { czynników lokalizacji }\end{array}$} & \multicolumn{3}{|c|}{ Firmy architektoniczne } & \multicolumn{3}{|c|}{ Firmy budowlane } \\
\hline & & $\begin{array}{c}\text { Średnia } \\
\text { ocena } \\
\text { w pkt }\end{array}$ & $\begin{array}{c}\text { Lączna } \\
\text { ocena } \\
\text { w } \%\end{array}$ & $\begin{array}{l}\text { Waga } \\
\mathrm{w} \%\end{array}$ & $\begin{array}{c}\text { Średnia } \\
\text { ocena } \\
\text { w pkt }\end{array}$ & $\begin{array}{c}\text { Lączna } \\
\text { ocena } \\
\text { w } \%\end{array}$ & $\begin{array}{l}\text { Waga } \\
\text { w } \%\end{array}$ \\
\hline 1. & Rynki zbytu & 4,60 & 23,00 & 92,00 & 3,50 & 18,06 & 70,00 \\
\hline 2. & Rynki zaopatrzenia & 2,20 & 11,00 & 44,00 & 2,63 & 13,55 & 52,50 \\
\hline 3. & Nieruchomości & 3,40 & 17,00 & 68,00 & 3,25 & 16,77 & 65,00 \\
\hline 4. & Infrastruktura transportowa & 2,60 & 13,00 & 52,00 & 3,00 & 15,48 & 60,00 \\
\hline 5. & Rynek pracy & 3,00 & 15,00 & 60,00 & 3,63 & 18,71 & 72,50 \\
\hline 6. & $\begin{array}{l}\text { Koszty prowadzenia } \\
\text { działalności gospodarczej }\end{array}$ & 4,20 & 21,00 & 84,00 & 3,38 & 17,42 & 67,50 \\
\hline
\end{tabular}

Źródło: opracowanie własne na podstawie wyników badań ankietowych.

Wyliczone wagi umożliwiły wykreślenie profili lokalizacyjnych dla firm architektonicznych i budowlanych (ryc. 3). Profile lokalizacyjne to wykresy stanowiące graficzne przedstawienie wagi poszczególnych grup czynników dla przedsiębiorstw uczestniczących w badaniach empirycznych. Podobną analizę przeprowadziła A. Tobolska (2011), wyznaczając profile lokalizacyjne dla trzech wybranych korporacji międzynarodowych.

Z perspektywy firm architektonicznych najistotniejszymi klasycznymi czynnikami lokalizacyjnymi okazały się być „,rynki zbytu” (92\%), „,koszty prowadzenia działalności gospodarczej (84\%) oraz - w nieco mniejszym stopniu - czynniki związane z nieruchomościami (68\%). Zdecydowanie najmniejsze znaczenie miały „rynki zaopatrzenia” (44\%).

Natomiast najistotniejsze czynniki lokalizacji dla firm budowlanych to: „rynek pracy” (72,5\%), „rynki zbytu” (70\%) oraz „koszty prowadzenia działalności gospodarczej (67,5\%). Zastanawiający jest fakt, iż najmniej istotną grupą czynników okazały się „rynki zaopatrzenia” $(52,5 \%)$. Wytłumaczeniem może tu być fakt, że przedsiębiorstwa budowlane, które uczestniczyły w badaniach ankietowych, przy realizacji zadań stanowiących podstawę ich działalności gospodarczej nie są odpowiedzialne za kwestie zaopatrzeniowe, a jedynie za prace ściśle budowlane. 
Ryc. 3. Profile lokalizacyjne dla firm architektonicznych oraz firm budowlanych według grup klasycznych czynników lokalizacji i ich wag

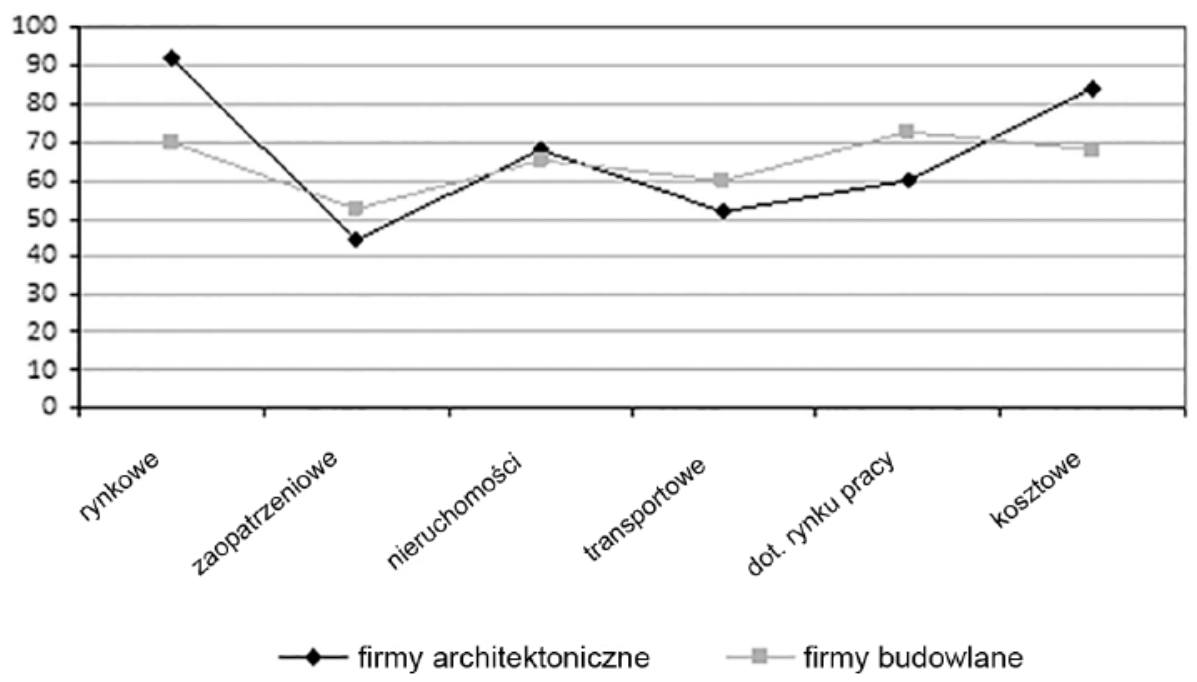

Źródło: opracowanie własne na podstawie wyników badań ankietowych.

Uzasadnieniem uzyskanych wyników analiz z całym przekonaniem może być charakter prowadzonej działalności gospodarczej. Podstawowym produktem oferowanym przez firmy architektoniczne na rynku są różnego typu projekty architektoniczne (np. projekty budynków, dróg, mostów). Z tej perspektywy kluczowe wydaje się być poszukiwanie rynku zbytu, tj. potencjalnych klientów zainteresowanych nabyciem tego typu produktów. Z perspektywy biura architektonicznego istotny wydaje się być również budynek, w którym owo biuro zostanie usytuowane. Ważna jest jego dostępność, miejsca parkingowe, ogólny wygląd (reprezentatywność), koszty wynajmu lub zakupu oraz wszelkie pozostałe koszty związane z utrzymaniem biura.

Natomiast charakter działalności prowadzonej przez przedsiębiorstwa budowlane wiąże się z koniecznością zatrudniania wielu pracowników mających odpowiednie kwalifikacje oraz doświadczenie (np. murarze, stolarze, elektrycy, dekarze, zbrojarze, kierownicy budowy). Stąd też rynek pracy i panująca na nim sytuacja, dostępność specjalistów, różnego typu fachowców, ale również poziom wynagrodzenia minimalnego czy kosztów związanych z zatrudnieniem pracownika mają tu istotne znaczenie. Aspekt ten bezpośrednio wiąże się również z kosztami prowadzenia działalności gospodarczej.

\section{Zakończenie}

Dogodna lokalizacja przedsiębiorstwa w przestrzeni gospodarczej stanowi jedno z ważniejszych źródeł przewagi konkurencyjnej i określa zarówno dostęp do czynników produkcji, jak i rynku zbytu czy też korzystniejszych rozwiązań fiskalnych. Pomimo gwałtownych przemian otoczenia, stanowiących rezultat globalizacji czy postępu technologicznego i informatycznego, klasyczne czynniki lokalizacji wciąż nie tracą na ważności. Uzyskane wyniki badań empirycznych przeprowadzonych na grupie przedsiębiorstw branży budowlanej dowodzą, że przedsiębiorcy są świadomi wagi miejsca usytuowania przedsiębiorstwa w przestrzeni gospodarczej dla powo- 
dzenia podjętego przedsięwzięcia. Dokonując wyboru określonej lokalizacji, rozpatrują zarówno czynniki rynkowe, kosztowe, jak i te dotyczące rynku zbytu czy nieruchomości.

Uzyskane wyniki badań dowiodły, że struktura ważności poszczególnych czynników w podejmowaniu decyzji zależna jest od specyfiki prowadzonej działalności gospodarczej. Inne czynniki istotne były dla firm architektonicznych i były to „rynki zbytu”, „koszty prowadzenia działalności gospodarczej, oraz czynniki związane z nieruchomościami. Natomiast z perspektywy firm budowlanych szczególnie istotne okazały się: „,rynek pracy”, „rynki zbytu” oraz „koszty prowadzenia działalności gospodarczej”.

Oczywiście poza klasycznymi czynnikami lokalizacji przedsiębiorstwa, którym poświęcono niniejszy artykuł, istnieje również szereg innych, równie istotnych współczesnych czynników lokalizacji, stanowiących odpowiedź na gwałtowne przemiany zachodzące w gospodarce (tzw. turbulentne otoczenie przedsiębiorstwa). Czynniki te omówione zostały w innym artykule (Płaziak, Szymańska, 2014). Kompozycja czynników lokalizacji, które przedsiębiorca powinien uwzględnić, dokonując wyboru miejsca, w którym prowadzona będzie działalność gospodarcza, uzależniona jest przede wszystkim od przedmiotu prowadzonej działalności.

\section{Literatura \\ References}

Budner, W. (2004). Lokalizacja przedsiębiorstw. Aspekty ekonomiczno-przestrzenne i środowiskowe. Poznań: Wyd. Akademii Ekonomicznej w Poznaniu.

Całczyński, A. (1981). Modele i metody lokalizacji ośrodków dystrybucyjnych. Monografie i Syntezy, 14. Warszawa: IWHIW.

Domański, R. (2011). Gospodarka przestrzenna. Podstawy teoretyczne. Warszawa: PWN.

Dorocki, S., Rachwał, T., Szymańska, A.I., Zdon-Korzeniowska, M. (2012). Spatial Conditions for Agritourism Development on the Example of Poland and France. Current Issues of Tourism Research, 2(2), 20-29.

Dorocki, S., Szymańska, A.I., Zdon-Korzeniowska, M. (2012). Polskie gospodarstwa agroturystyczne jako przedsiębiorstwa rodzinne. Przedsiębiorczość i Zarzadzanie, 8(8), 45-60

Dorocki, S., Szymańska, A.I., Zdon-Korzeniowska M. (2013a). Polskie gospodarstwa agroturystyczne w dobie kryzysu gospodarczego. Przedsiębiorczość - Edukacja, 9.

Dorocki, S., Szymańska, A.I., Zdon-Korzeniowska, M. (2013b). Agricultural tourism farms in Poland how the farmers improve their businesses - the case study. Understanding Innovation in Emerging Economic Spaces, IGU-Ashgate.

Dziemianowicz, W. (1997). Kapitał zagraniczny a rozwój regionalny i lokalny w Polsce. Studia Regionalne i Lokalne, 21.

Fabińska, M., Piasecki, T., Benchmarking regionalny, Społeczna Wyższa Szkoła Przedsiębiorczości i Zarządzania w Łodzi, http://www.eedri.pl/pdf/187.pdf (data odczytu: 20.10.2013).

Fierla, I., Kuciński, K. (red.). (2001). Lokalizacja przedsiębiorstw a konkurencyjność. Warszawa: Wyd. Szkoły Głównej Handlowej w Warszawie.

Hoover, E.M. (1962). Lokalizacja działalności gospodarczej. Warszawa: PWN, 16-19.

Isard, W. (1956). Location and Space-economy. New York: J. Wiley and Sons.

Kupiec, L. (red.). (1999). Gospodarka przestrzenna. Lokalizacja w gospodarce przestrzennej, 33. Białystok: Wydawnictwo Uniwersytetu w Białymstoku.

Leśniak, J. (1985). Planowanie przestrzenne. Warszawa: PWN.

Lösch, A. (1940). Die räumliche Ordnung der Wirtschaft. Jena.

Perreur, J. (1992). Lokalizacja jednostek produkcyjnych. W: C. Ponsard (red.), Ekonomiczna analiza przestrzenna. Poznań: Wydawnictwo Akademii Ekonomicznej w Poznaniu. 
Płaziak, M., Szymańska, A.I. (2014). Enterprise and Classical Factors of its Location on the market. Procedia. Social and Behavioral Sciences, 120, 13-22.

Płaziak, M. Szymańska, A.I. (2014). Role of modern factors in the process of choosing a location of an enterprise. Procedia. Social and Behavioral Sciences, 120, 72-83.

Pred, A.R. (1967). Behaviour and Location: Foundations for a Geographic Dynamic Location Theory. Part 1. Lund 1967, Studies in Geography, Series B. 27.

Rachwał, T. (2011a). Industrial restructuring in Poland and other European Union states in the era of economic globalization. Procedia. Social and Behavioral Sciences, 19, 1-10.

Rachwał, T. (2011b). Transformations of the employment structure as an expression of the transformation of the Polish industry against the background of the European Union. Bulletin of Geography, Socio-economic series, $15,5-25$.

Rachwał, T. (2011c). Wpływ kryzysu na zmiany produkcji przemysłowej w Polsce. Prace Komisji Geografii Przemystu Polskiego Towarzystwa Geograficznego, 17, 99-113.

Rachwał, T., Wiedermann, K. (2008). Multiplier effects in regional development: The case of the motor vehicle industry in Silesian voivodeship (Poland), Quaestiones Geographicae, 27B/1, 67-80.

Raźniak, P. (2012). Wpływ poziomu bezpieczeństwa społecznego na migracje ludności w Polsce. Bezpieczeństwo. Teoria i Praktyka, 4, 41-52.

Raźniak, P., Winiarczyk-Raźniak, A. (2013). Spatial distribution and differences in migration patterns and revenues of gminas in the Kraków Metropolitan Area. Bulletin of Geography. Socio-economic Series, 19, 73-86.

Stryjakiewicz, T. (2009). Nowe spojrzenie na czynniki lokalizacji działalności gospodarczej. W: I. Jażewicz (red.) Współczesne problemy przemian strukturalnych przestrzeni geograficznej. Słupsk: Wydawnictwo Naukowe Akademii Pomorskiej, 94-102.

Tobolska, A. (2011). Czynniki lokalizacji fabryk wybranych korporacji międzynarodowych w Polsce. W: M. Wdowicka, L. Mierzejewska (red.), Problemy rozwoju lokalnego i regionalnego na początku XXI wieku. Rozwój Regionalny i Polityka Regionalna, Biuletyn Instytutu Geografii Społeczno-Ekonomicznej i Gospodarki Przestrzennej UAM, 15.

Wieloński, A. (2004). Lokalizacja działalności gospodarczej. Teoretyczne podstawy. Warszawa: Wydawnictwo Uniwersytetu Warszawskiego.

Zawadzki, S.M. (1973). Polska, przestrzeń, społeczeństwo. Warszawa: PWE.

Anna Irena Szymańska, doktor, Uniwersytet Pedagogiczny im. Komisji Edukacji Narodowej w Krakowie, Zakład Przedsiębiorczości i Gospodarki Przestrzennej.

Absolwentka studiów z zakresu zarządzania i marketingu Uniwersytetu Ekonomicznego w Krakowie, doktor nauk ekonomicznych w zakresie nauk o zarządzaniu (Katedra Analizy Rynku i Badań Rynkowych - Uniwersytet Ekonomiczny w Krakowie). Adiunkt w Zakładzie Przedsiębiorczości i Gospodarki Przestrzennej Uniwersytetu Pedagogicznego w Krakowie. Zainteresowania badawcze autorki oscylują wokół problematyki potrzeb, preferencji i zachowań rynkowych konsumentów, jak również zagadnień z obszaru przedsiębiorczości i innowacyjności przedsiębiorstw ze szczególnym uwzględnieniem sektora MŚP.

Anna Irena Szymańska, PhD, Pedagogical University of Cracow, Institute of Geography, Department of Entrepreneurship and Spatial Management.

The author graduated from the University of Economics in Cracow. She obtained a MA degree in management and marketing, a $\mathrm{PhD}$ degree in economic sciences in the field of management sciences (the chair of Market Analysis and Marketing Research - the University of Economics in Krakow). At present, Anna Irena Szymańska is an assistant professor in the Department of Entrepreneurship and Spatial Management at Pedagogical University of Cracow. Her research interests relate to the issue of consumer needs, preferences and market behaviour as well as issues in the area of entrepreneurship and innovation with particular emphasis on the SME sector. 
Monika Plaziak,

Monika Plaziak,

Adres/Address: doktor, adiunkt, Uniwersytet Pedagogiczny, Instytut Geografii, Zakład Przedsiębiorczości i Gospodarki Przestrzennej.

Zainteresowania badawcze autorki dotyczą zagadnień gospodarki przestrzennej w kontekście czynników lokalizacji przedsiębiorstw, szczególnie czynnika personalnego. Prace badawcze odnoszą się również do zagadnień współpracy jednostek naukowych i badawczo-rozwojowych z sektorem MŚP, zwłaszcza w zakresie wdrażania nowych technologii i materiałów, w tym dotyczących budownictwa energooszczędnego i pasywnego. Ponadto, autorka zajmuje się problematyką poziomu i jakości życia ludności, ze szczególnym uwzględnieniem małych i średnich miast Polski oraz miast postsocjalistycznych.

$\mathrm{PhD}$, Pedagogical University of Cracow, Institute of Geography, Department of Entrepreneurship and Spatial Management.

The research interests of the author concern issues of the spatial development in the context of location factors of enterprises, and especially the personal factor. The research works also refer to the issues of cooperation of scientific and research-developmental organizations with the sector of small and mediumsized enterprises, especially in the field of implementing new technologies and materials for the energy-efficient and passive building. Additionally, the author analyses issues of the level and quality of life, with particular reference to small and medium-sized towns in Poland, and the post socialist towns.

Uniwersytet Pedagogiczny im. Komisji Edukacji Narodowej w Krakowie ul. Podchorążych 2

30-084 Kraków, Polska

e-mail: aszym@up.krakow.pl

e-mail:mplaziak@up.krakow.pl 